\title{
POSSIBILITIES OF WHEAT FARMING ON SOILS CONTAMINATED WITH HEAVY METALS IN THE REGION OF NFMW - PLOVDIV, BULGARIA
}

\author{
Miroslava Ivanova ${ }^{1}$, Lilko Dospatliev ${ }^{2}$, Antoniya Stoyanova ${ }^{3}$ \& Nikolay Valchev ${ }^{3}$ \\ ${ }^{1}$ Department of Informatics and Mathematics, Faculty of Economics, Trakia University \\ Student campus, Stara Zagora 6000, Bulgaria, e-mail: mivanova_tru@abv.bg \\ ${ }^{2}$ Department of Pharmacology, Animal Physiology and Physiological Chemistry, Faculty of \\ Veterinary Medicine, Trakia University Student campus, Stara Zagora 6000, Bulgaria; \\ ${ }^{3}$ Department of Plant Production, Faculty of Agriculture, Trakia University, Student campus, \\ Stara Zagora 6000, Bulgaria
}

\begin{abstract}
The subject of present comparative study in the region of the NFMW Plovdiv, Bulgaria, was to evaluate the amounts and depots of accumulated $\mathrm{Pb}, \mathrm{Cu}, \mathrm{Zn}$ and $\mathrm{Cd}$ in vegetative and reproductive organs of the cereal crop wheat, as well as to determine the possibilities for wheat farming on soils contaminated with heavy metals. The highest heavy metal concentrations were established in the grain of wheat farmed at a distance of $100 \mathrm{~m}$ from NFMW where Pb attained up to $10.689 \mathrm{mg} \cdot \mathrm{kg}^{-1}, \mathrm{Zn}$ - up to $71.458 \mathrm{mg} \cdot \mathrm{kg}^{-1}, \mathrm{Cu}$ - up to $4.583 \mathrm{mg} \cdot \mathrm{kg}^{-1}$ and $\mathrm{Cd}-$ up to $1.211 \mathrm{mg} \cdot \mathrm{kg}^{-1}$. As the distance from the plant increased, a very marked trend to reduction of heavy metal contents in wheat grain was observed. In grains of wheat reared $7000 \mathrm{~m}$ away from NFMW, Pb decreased up to $0.008 \mathrm{mg} . \mathrm{kg}^{-1}, \mathrm{Zn}$ - up to $29.265 \mathrm{mg} \cdot \mathrm{kg}^{-1}$, Cu up to $3.986 \mathrm{mg} \cdot \mathrm{kg}^{-1}$ and $\mathrm{Cd}$ up to $0.021 \mathrm{mg} \cdot \mathrm{kg}^{-1}$. The strongest relationship among the total amount of studied metals in the soil and their respective contents in roots, stems, leaves, bracts and grain was established for $\mathrm{Zn}$ (0.998). The distribution of heavy metals in the organs of the studied cereal crop was selective in the following descending order: root > leaves > stem > bracts > grain. It was found out that the grain and aerial parts of wheat could not be used for food by humans and animals. Also, wheat could be farmed in industrially polluted areas only if intended for seed production or processing - the grain could be used in ethanol production, and straw - for production of cellulose.
\end{abstract}

Keywords: heavy metals, polluted soils, intake, wheat, NFMW - Plovdiv, Bulgaria.

\section{INTRODUCTION}

Cadmium $(\mathrm{Cd})$ and lead $(\mathrm{Pb})$ are nonessential elements that are toxic to plants and animals, while zinc $(\mathrm{Zn})$ and copper $(\mathrm{Cu})$ play essential metabolic roles in plants and animals $[1,2]$. It is known that only a small amount of the total $\mathrm{Pb}$ in soils may be taken up by plants, and the translocation of $\mathrm{Pb}$ from roots to tops is greatly limited [3-5]. Cd, $\mathrm{Zn}$, and Cu can be more readily taken up by plants and relatively high concentrations may occur in crops for human consumption. The amount of $\mathrm{Pb}, \mathrm{Cd}$, and $\mathrm{Zn}$ taken up by plants depends on the total amounts in the soil and their availability [6,7]. The availability of heavy metals is influenced by a wide range of factors, including soil $\mathrm{pH}$, organic matter, carbonates, clay minerals, and oxides [2,8-10].

Toxic metals are accumulated in plants, and animals fed with these plants will tend to accumulate toxic metals themselves. Although contamination of animal feed by toxic metals cannot be entirely avoided given the prevalence of these pollutants in the environment, there is a clear need for such contamination to be minimized, with the aim of reducing both direct effects on animal health and indirect effects on human health. Toxic effects of metals have been described in animals under relatively low levels of metal exposure [11,12] and one of

IRTIIE Vol. 5, No. 2, 2017 ISSN 1314-8788 (print), ISSN 1314-8796 (online), doi: 10.15547/artte.2017.02.008 


\section{IRTITE

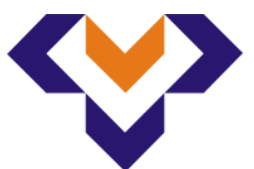 \\ Ipplied Researthes in Technics, Technologies and Bdurition \\ Journal of the Faculty of Technics and Technologies, Trakia University https://sites.google.com/a/trakia-uni.bg/artte/}

the earliest effects is the disruption of trace element metabolism [13,14]. Pb interacts with calcium $(\mathrm{Ca})$ in the nervous system to impair cognitive development. Cd interacts with $\mathrm{Ca}$ in the skeletal system to produce osteodystrophies. $\mathrm{Pb}$ replaces $\mathrm{Zn}$ on heme enzymes and $\mathrm{Cd}$ replaces $\mathrm{Zn}$ on metallothionein.

The need to reduce toxic metal contamination in animal feed in fact poses a significant problem for agricultural regions located in more-or-less industrialized areas in which animals are reared on locally produced feed. There are many such regions worldwide, including in Bulgaria. The district near the Rhodopi Mountain and the Plovdiv Field has been exposed to the influence of the Non-ferrous Metal Works (NFMW) for a long period of time. In the vicinity of the NFMW near Plovdiv, more than 2,100 ha have been polluted by heavy metals. It is estimated that approximately 460 tons of dust, containing mainly $\mathrm{Pb}$, with less $\mathrm{Zn}$ and $\mathrm{Cd}$, have been annually released into the atmosphere for more than 40 years $[15,18]$. As a result of the new cleansing facilities built in the NFMW, however, the aerosol pollution in the district has been reduced to a minimum. This makes it extremely appropriate to examine the connection between soil and plants regarding the assimilation of heavy metals. This area possesses high levels of heavy metals in soils and in vegetation [19-23].

The aim of the present work was to evaluate the bioavailability of heavy metals in the soilplant system. This involved an investigation of the connection between the total quantity and the mobile forms of $\mathrm{Pb}, \mathrm{Cd}, \mathrm{Zn}$, and $\mathrm{Cu}$ in soils of varying levels of contamination; the transition of these metals into wheat.

\section{METHODS}

\subsection{Soils}

Soils used in this experiment were sampled from the vicinity of the area contaminated by the NFMW near Plovdiv, Bulgaria. Soils were collected from the surface (0 to $30 \mathrm{~cm}$ depth) of fields located at different distances $(100,400,800,2000$ and $7000 \mathrm{~m})$ from the NFMW. The investigated soils are characterized by alkaline reaction, moderate $\mathrm{CaCO}_{3}$ content, loamy texture, and moderate content of organic matter (Table 1). The soil samples were air dried, homogenized in an agitate mortar, and sieved. A fraction with particle size $<1 \mathrm{~mm}$ was taken for analysis.

Table 1. Soil Properties for Soil Sampled from the NFMW near Plovdiv

\begin{tabular}{|c|c|c|c|c|c|}
\hline $\begin{array}{c}\text { Distance } \\
\text { from NFMW } \\
\text { (m) }\end{array}$ & $\mathrm{pH}\left(\mathrm{H}_{2} \mathrm{O}\right)$ & $\begin{array}{c}\mathrm{CaCO}_{3} \\
(\%)\end{array}$ & $\begin{array}{c}\text { Humus } \\
(\%)\end{array}$ & $\begin{array}{l}\text { III } \\
(\%)\end{array}$ & $\begin{array}{c}\text { Clay } \\
(\%)\end{array}$ \\
\hline 100 & 7.2 & 3.7 & 2.12 & 16.85 & 36.52 \\
\hline 400 & 7.8 & 8.2 & 1.21 & 25.64 & 42.75 \\
\hline 800 & 7.6 & 3.8 & 1.10 & 14.92 & 26.31 \\
\hline 2000 & 7.5 & 5.6 & 1.31 & 12.21 & 24.75 \\
\hline 7000 & 7.9 & 6.2 & 2.41 & 27.81 & 48.13 \\
\hline
\end{tabular}

\subsection{Plants}

The wheat was grown in the same regions situated at different distances $(100,400,800$, 2000 and $7000 \mathrm{~m}$ ) from the NFMW - Plovdiv. On reaching the "blossoming" stage, the wheat was gathered, and the content of $\mathrm{Pb}, \mathrm{Cd}, \mathrm{Zn}$, and $\mathrm{Cu}$ in the different parts (stems, leaves, and inflorescences) was quantitatively determined. The samples were treated by the method of dry ashing. 


\section{ARTTIE $Y$}

Ipplied Researrohes in Technics, Technologies and Bductition

Journal of the Faculty of Technics and Technologies, Trakia University https://sites.google.com/a/trakia-uni.bg/artte/

\subsection{Heavy Metal Analysis}

\subsubsection{Sample Preparation}

\subsubsection{Soils}

Total content of heavy metals in soils was determined in accordance with the international standard for extraction of trace elements soluble in aqua regia ISO 11466, 1995. Three grams of soil sample were decomposed on a sand bath heater for $3 \mathrm{~h}$ with $21 \mathrm{ml}$ of concentrated hydrochloric acid $(\mathrm{HCl})+7 \mathrm{ml}$ of concentrated nitric acid $\left(\mathrm{HNO}_{3}\right)$. After cooling the sample, the residue was transferred into a 50 - $\mathrm{ml}$ flask and water was added up to the mark.

Fractionation studies - The distribution of heavy metals in the different forms and phases in which they occur in soil can be determined using sequential extraction procedures. Sequentialextraction procedures provide information about the determination of the relative binding strength of the metal on various solid phases and about their potential reactivity under physicochemical environmental conditions. In the present study, a five-step Tessier sequential extraction scheme [24], separating exchangeable metals, metals bound to carbonates, metals bound to Fe-Mn oxides, metals bound to organic matter, and residual metals, was applied for the extraction of metals in soil samples for assessing the mobility of the metals.

\subsection{Plants}

A 1 - g. sample was weighed into a quartz crucible and put into a furnace $\left(525^{\circ} \mathrm{C}\right)$ until ashing occurred. After cooling to room temperature, $1 \mathrm{ml} \mathrm{HNO}_{3}(1: 1)$ was added, evaporated in a sand bath, and put again into the furnace $\left(525^{\circ} \mathrm{C}\right)$. The procedures were repeated until the ash was white. It was finally dissolved in $2 \mathrm{ml} 20 \% \mathrm{HCl}(\mathrm{v} / \mathrm{v})$, transferred into a graduated $25-\mathrm{ml}$ flask, and brought to volume with doubly distilled water.

\subsection{Equipment}

In the determination of heavy metals in the soils and plants samples Atomno absorption spectrometer "AAnalyst 800 with graphite furnace HGA" Company "Perkin Elmer", at wavelengths: $\mathrm{Pb}-217.0 \mathrm{~nm}, \mathrm{Cd}-228.8 \mathrm{~nm}, \mathrm{Cu}-324.8 \mathrm{~nm}$ and $\mathrm{Zn}-213.9 \mathrm{~nm}$ was used.

\section{EXPERIMENTAL}

\subsection{Soils}

\subsubsection{Total content}

According to the results, the content of $\mathrm{Pb}, \mathrm{Cd}$ and $\mathrm{Zn}$ in soils was considerably higher than the background levels of these heavy metals in the natural type of soil in the region.

Lead: The total $\mathrm{Pb}$ content in analysed soils varied from $27.3 \mathrm{mg} \cdot \mathrm{kg}^{-1}$ to $913.2 \mathrm{mg} \cdot \mathrm{kg}^{-1}$. The maximum permissible limit (MPL) for $\mathrm{Pb}$ as per Ordinance 3/2008 stipulating norms for permissible content of harmful substances in soils is $120 \mathrm{mg} \cdot \mathrm{kg}^{-1}$. 


\section{IPITIP Journal of the Faculty of Technics and Technologies, Trakia University https://sites.google.com/a/trakia-uni.bg/artte/}

Zinc: The total Zn content in analysed soils varied from $36.8 \mathrm{mg} \cdot \mathrm{kg}^{-1}$ to $1928.2 \mathrm{mg} \cdot \mathrm{kg}^{-1}$. The maximum permissible limit (MPL) for $\mathrm{Zn}$ as per Ordinance $3 / 2008$ stipulating norms for permissible content of harmful substances in soils is $400 \mathrm{mg}^{\mathrm{kg}}{ }^{-1}$.

Cadmium: The total Cd content in analysed soils varied from $2.8 \mathrm{mg} . \mathrm{kg}^{-1}$ to $27.9 \mathrm{mg} \cdot \mathrm{kg}^{-1}$. The maximum permissible limit (MPL) for $\mathrm{Cd}$ as per Ordinance 3/2008 stipulating norms for permissible content of harmful substances in soils is $3.0 \mathrm{mg} \cdot \mathrm{kg}^{-1}$.

Copper (Cu): The total $\mathrm{Cu}$ content in analysed soils varied from $17.66 \mathrm{mg} \cdot \mathrm{kg}^{-1}$ to 172.43 $\mathrm{mg} \cdot \mathrm{kg}^{-1}$. The maximum permissible limit (MPL) for $\mathrm{Cu}$ as per Ordinance 3/2008 stipulating norms for permissible content of harmful substances in soils is $300 \mathrm{mg}^{-\mathrm{kg}^{-1}}$.

\subsubsection{Fractionation of Soil}

Figure 1, Figure 2, Figure 3 and Figure 4 presents mean values (in \%) of metal associated with different fractions (exchangeable metals, metals bound to carbonates, metals bound to Fe-Mn oxides, metals bound to organic matter, and residual metals).

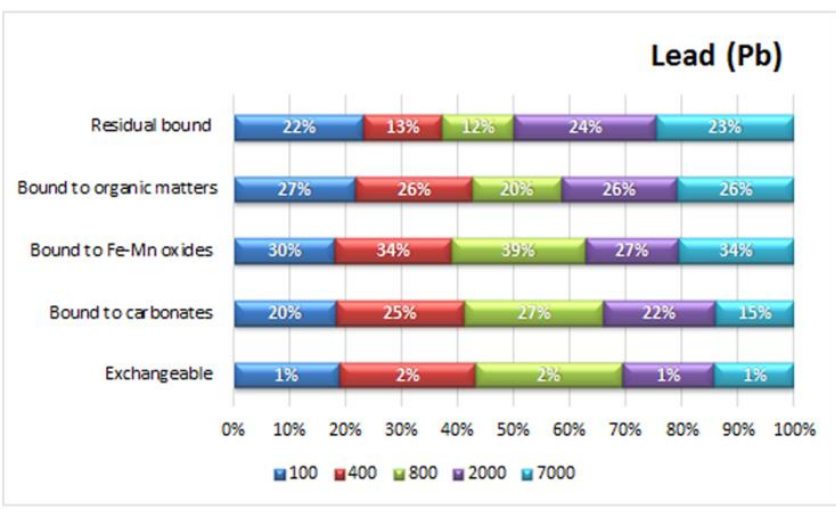

Figure 1.

Association of $\mathrm{Pb}$ with different fractions of soils of the study area

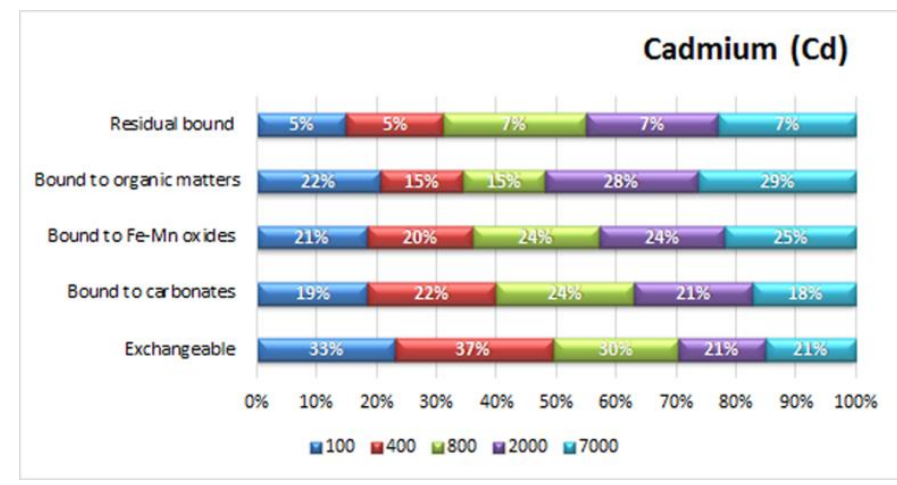

Figure 2.

Association of $\mathrm{Cd}$ with different fractions of soils of the study area 


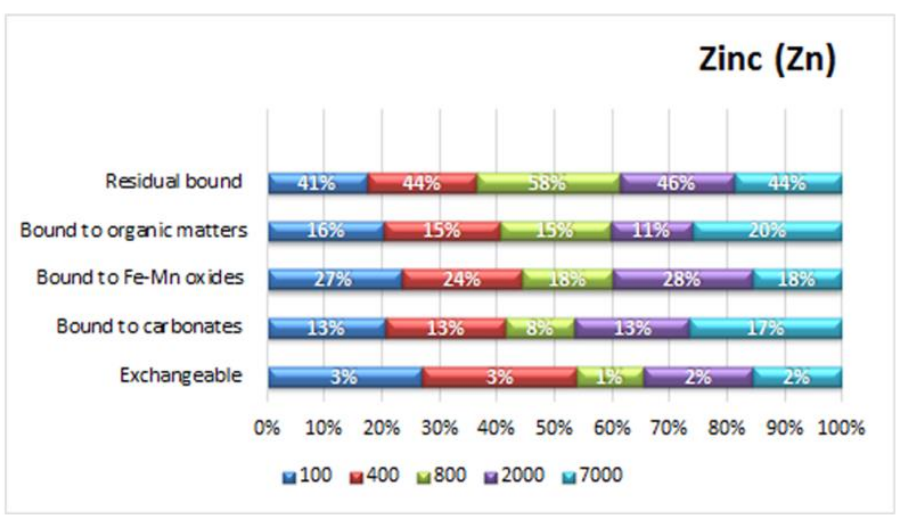

Figure 3. Association of $\mathrm{Zn}$ with different fractions of soils of the study area

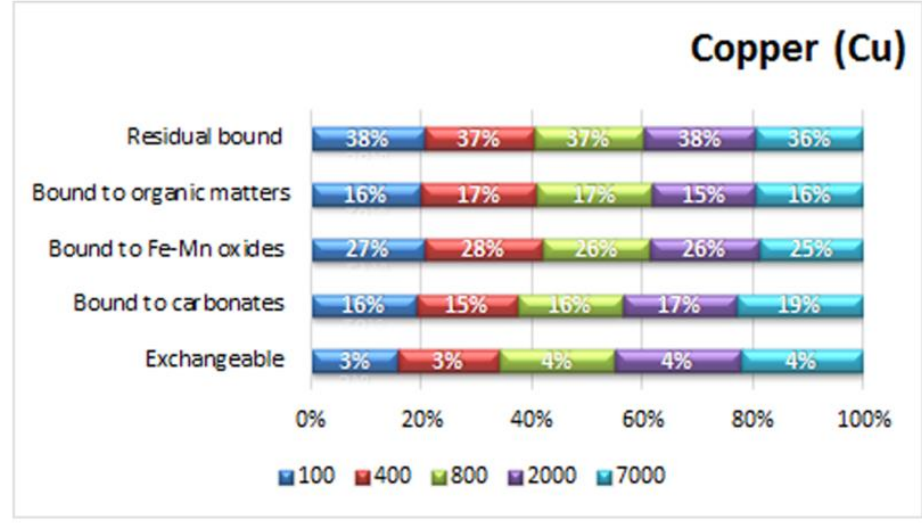

Figure 4. Association of $\mathrm{Cu}$ with different fractions of soils of the study area

\subsection{Plants}

\subsubsection{Content of $\mathrm{Pb}, \mathrm{Zn}, \mathrm{Cu}$ and $\mathrm{Cd}$ in vegetative and reproductive organs of wheat}

For elucidation of issues related to absorption, distribution and accumulation of heavy metals in vegetative and reproductive organs of wheat, samples collected from roots, stems, leaves, bracts and grain were analysed.The data from the analysis of $\mathrm{Pb}, \mathrm{Zn}, \mathrm{Cu}$ and $\mathrm{Cd}$ in wheat are presented in Tables 2, 3, 4 and 5.

Table 2. Contents of $\mathrm{Pb}\left(\mathrm{mg}^{\mathrm{kg}} \mathrm{kg}^{-1}\right)$ in wheat

\begin{tabular}{cccccc}
$\begin{array}{c}\text { Distance } \\
\text { from NFMW } \\
(\mathbf{m})\end{array}$ & Roots & Stems & Leaves & Bracts & Grain \\
\hline & & MPL for $\mathrm{Pb}-0.5 \mathrm{mg}^{\mathrm{k} \mathrm{kg}^{-1}}$ & & \\
100 & 81.357 & 0.362 & 92.421 & 28.965 & 10.689 \\
400 & 52.485 & 0.132 & 56.205 & 16.432 & 3.745 \\
800 & 20.354 & 0.096 & 28.362 & 4.853 & 0.636 \\
2000 & 8.415 & 0.061 & 7.875 & 0.754 & 0.241 \\
7000 & 5.467 & 0.046 & 1.946 & 0.012 & 0.008 \\
\hline
\end{tabular}

MPL - Maximum permissible limit (Ordinance № 31/2004; Directive 99/29/EC)

${ }^{*}$ Average value $\left(\mathrm{mg}^{\mathrm{kg}}{ }^{-1}\right)$ from five repetitions

IRITIE Vol. 5, No. 2, 2017 ISSN 1314-8788 (print), ISSN 1314-8796 (online), doi: 10.15547/artte.2017.02.008 
Table 3. Contents of $\mathrm{Zn}\left(\mathrm{mg}^{\mathrm{kg}} \mathrm{kg}^{-1}\right)$ in wheat

\begin{tabular}{cccccc}
\hline $\begin{array}{c}\text { Distance } \\
\text { from NFMW } \\
(\mathbf{m})\end{array}$ & Roots & Stems & Leaves & Bracts & Grain \\
\hline \multicolumn{5}{c}{ MPL for $\mathrm{Zn}-40{\mathrm{mg} \cdot \mathrm{kg}^{-1}}^{-1}$} \\
100 & 172.185 & 29.426 & 228.329 & 118.345 & 71.458 \\
400 & 96.542 & 16.069 & 165.529 & 74.730 & 52.364 \\
800 & 81.165 & 14.685 & 108.104 & 45.206 & 35.167 \\
2000 & 63.542 & 13.745 & 47.026 & 34.543 & 31.491 \\
7000 & 59.862 & 11.325 & 27.192 & 23.574 & 29.265 \\
\hline
\end{tabular}

MPL - Maximum permissible limit (Ordinance № 31/2004; Directive 99/29/EC).

${ }^{*}$ Average value $\left(\mathrm{mg} \mathrm{kg}^{-1}\right)$ from five repetitions

Table 4. Contents of $\mathrm{Cu}\left(\mathrm{mg} \cdot \mathrm{kg}^{-1}\right)$ in wheat

\begin{tabular}{cccccc}
$\begin{array}{c}\text { Distance } \\
\text { from NFMW } \\
(\mathbf{m})\end{array}$ & Roots & Stems & Leaves & Bracts & Grain \\
\hline & & MPL for $\mathrm{Cu}-10 \mathrm{mg} \cdot \mathrm{kg}^{-1}$ \\
100 & 12.147 & 2.548 & 12.957 & 4.843 & 4.583 \\
400 & 10.874 & 2.565 & 8.321 & 4.591 & 4.416 \\
800 & 10.168 & 2.692 & 4.832 & 4.364 & 4.285 \\
2000 & 8.365 & 2.645 & 3.109 & 3.211 & 4.065 \\
7000 & 7.538 & 2.625 & 2.746 & 3.574 & 3.986 \\
\hline
\end{tabular}

MPL - Maximum permissible limit (Ordinance № 31/2004; Directive 99/29/EC).

${ }^{*}$ Average value $\left(\mathrm{mg} \cdot \mathrm{kg}^{-1}\right)$ from five repetitions

Table 5. Contents of $\mathrm{Cd}\left(\mathrm{mg} \cdot \mathrm{kg}^{-1}\right)$ in wheat

\begin{tabular}{cccccc}
$\begin{array}{c}\text { Distance } \\
\text { from NFMW } \\
(\mathbf{m})\end{array}$ & Roots & Stems & Leaves & Bracts & Grain \\
& & \multicolumn{5}{c}{ MPL for Cd -0.1 mg.kg } \\
& & 0.626 & 10.326 & 22.717 & 1.211 \\
100 & 4.834 & 0.375 & 6.351 & 9.864 & 0.932 \\
400 & 2.854 & 0.252 & 3.437 & 4.721 & 0.543 \\
800 & 1.365 & 0.161 & 1.254 & 1.524 & 0.073 \\
2000 & 0.921 & 0.124 & 0.567 & 0.421 & 0.021 \\
7000 & 0.635 & 0.124 &
\end{tabular}

MPL - Maximum permissible limit (Ordinance № 31/2004; Directive 99/29/EC).

${ }^{*}$ Average value $\left(\mathrm{mg}^{\mathrm{kg}}{ }^{-1}\right)$ from five repetitions

\subsection{Statistical analysis of results}

The statistical analysis of results was done with SPSS for Windows software.

The results presented in Tables 6, 7 and 8 demonstrated positive correlation $(r>0)$ and a strong linear relationship between variables $(r>0.8)$. Table 9 shows a negative relationship $(r<0)$ between soil $\mathrm{Cu}$ content and its content in leaves. 
Table 6. Relationships between the total $\mathrm{Pb}$ content in soil vs its content in roots, stems, leaves, bracts and grain

\begin{tabular}{lcccccc}
\hline & $\begin{array}{c}\text { The total Pb } \\
\text { content in } \\
\text { soil }\end{array}$ & Roots & Stems & Leaves & Bracts & Grain \\
\hline $\begin{array}{l}\text { The total Pb content } \\
\text { in soil }\end{array}$ & 1 & & & & & \\
Roots & 0.924 & 1 & & & & \\
Stems & 0.997 & 0.934 & 1 & & & \\
Leaves & 0.924 & 0.995 & 0.941 & 1 & & \\
Bracts & 0.942 & 0.999 & 0.950 & 0.993 & 1 & \\
Grain & 0.992 & 0.962 & 0.989 & 0.955 & 0.974 & 1 \\
\hline
\end{tabular}

Table 7. Relationships between the total $\mathrm{Zn}$ content in soil vs its content in roots, stems, leaves, bracts and grain

\begin{tabular}{c}
$\begin{array}{c}\text { The total } \mathrm{Zn} \\
\text { content in soil }\end{array}$ Roots Stems Leaves Bracts Grain \\
\hline
\end{tabular}

\begin{tabular}{lcccccc}
\hline $\begin{array}{l}\text { The total Zn content in } \\
\text { soil }\end{array}$ & 1 & & & & & \\
Roots & 0.998 & 1 & & & & \\
Stems & 0.994 & 0.990 & 1 & & & \\
Leaves & 0.906 & 0.927 & 0.882 & 1 & & \\
Bracts & 0.961 & 0.976 & 0.952 & 0.975 & 1 & \\
Grain & 0.950 & 0.969 & 0.939 & 0.964 & 0.996 & 1 \\
\hline
\end{tabular}

Table 8. Relationships between the total $\mathrm{Cd}$ content in soil vs its content in roots, stems, leaves, bracts and grain

The total Cd
content in Roots Stems Leaves Bracts Grain
soil

\begin{tabular}{lcccccc}
\hline $\begin{array}{l}\text { The total Cd content } \\
\text { in soil }\end{array}$ & 1 & & & & & \\
Roots & 0.996 & 1 & & & & \\
Stems & 0.990 & 0.995 & 1 & & & \\
Leaves & 0.979 & 0.992 & 0.995 & 1 & & \\
Bracts & 0.995 & 0.993 & 0.996 & 0.983 & 1 & \\
Grain & 0.920 & 0.946 & 0.954 & 0.978 & 0.926 & 1 \\
\hline
\end{tabular}


Table 9. Relationships between the total $\mathrm{Cu}$ content in soil vs its content in roots, stems, leaves, bracts and grain

\begin{tabular}{lcccccc}
\hline & $\begin{array}{c}\text { The total Cu } \\
\text { content in soil }\end{array}$ & Roots & Stems & Leaves & Bracts & Grain \\
\hline $\begin{array}{l}\text { The total Cu content } \\
\text { in soil }\end{array}$ & 1 & & & & & \\
Roots & 0.968 & 1 & & & & \\
Stems & -0.671 & -0.563 & 1 & & & \\
Leaves & 0.985 & 0.933 & -0.783 & 1 & & \\
Bracts & 0.871 & 0.931 & -0.525 & 0.862 & 1 & \\
Grain & 0.976 & 0.997 & -0.622 & 0.954 & 0.937 & 1 \\
\hline
\end{tabular}

\section{RESULTS}

\subsection{Soils}

\subsubsection{Fractionation of Soil}

Any metals derived from an anthropogenic source are strongly influenced by their form, phase, and oxidation state, and hence, bioavailability. Chemical soil tests are designed to extract a quantity ofelements from the soil solids that correlate statistically to the size of the "available pool" in the soil defined by the quantity of elements taken by the plants $[2,8]$. Chemical extraction techniques provide a wellestablished means of identifying and characterizing different fractions of heavy metals in the soil [25].

Results of the geochemical partitioning using the Tessier scheme revealed high concentrations of $\mathrm{Cd}$ to be associated with the mobile fraction of the soil. Most of the $\mathrm{Pb}, \mathrm{Cu}$, and $\mathrm{Zn}$ were bound with forms largely unavailable for plants, i.e., Fe-Mn oxides and residual fraction.

Because $\mathrm{Pb}$ binds strongly with organic matter and chemisorbs on oxides of $\mathrm{Fe}, \mathrm{Mn}$, and $\mathrm{Al}$, it is a low-mobility metal in soil. Studies have reported that accumulation of $\mathrm{Pb}$ in plants occurs only with high concentration of $\mathrm{Pb}$ in soils $[6,26]$. As the soil $\mathrm{Pb}$ concentration was high, the vegetation is prone to accumulate $\mathrm{Pb}[2,8]$.

\subsection{Plants}

\subsection{1. $\mathrm{Pb}, \mathrm{Zn}, \mathrm{Cu}$ and $\mathrm{Cd}$ content in the root system}

The root system is the main pathway for occurrence of heavy metals in plants. Once in roots, they could be either stored or transported to stems.

There were significant differences in the distribution of studied metals in the different parts of the plants. A substantial part of all four heavy metals was accumulated in roots, as also reported by other researchers [26-30]. This is attributed to the fact that after penetration in the plasma, the occurring inactivation and accumulation of important amounts of heavy metals was probably a result from formation of less mobile chelation compounds with organic matter.

The highest concentrations were established in wheat farmed at a distance of $100 \mathrm{~m}$ from NFMW where $\mathrm{Pb}$ attained up to $81.357 \mathrm{mg} \cdot \mathrm{kg}^{-1}, \mathrm{Zn}-172.185 \mathrm{mg} \cdot \mathrm{kg}^{-1}, \mathrm{Cu}-12.147 \mathrm{mg} \cdot \mathrm{kg}^{-1}$ and $\mathrm{Cd}-4.834 \mathrm{mg} \cdot \mathrm{kg}^{-1}$. As the distance from the NGMW increased, a clear tendency for reduction of heavy metal contents in wheat roots was observed. Seven thousand meters away from the NFMW, wheat roots $\mathrm{Pb}$ content was reduced up $5.467 \mathrm{mg} \cdot \mathrm{kg}^{-1}, \mathrm{Zn}$ content up to $59.862 \mathrm{mg} \cdot \mathrm{kg}^{-1}, \mathrm{Cu}-\mathrm{up}$ to $7.538 \mathrm{mg} \cdot \mathrm{kg}^{-1}$ and $\mathrm{Cd}-$ up to $0.635 \mathrm{mg} \cdot \mathrm{kg}^{-1}$.

IRTIIE Vol. 5, No. 2, 2017 ISSN 1314-8788 (print), ISSN 1314-8796 (online), doi: 10.15547/artte.2017.02.008 


\section{ART'TE \\ Ipplied Reseitrches in Technics, Technologies and Bducition \\ Journal of the Faculty of Technics and Technologies, Trakia University https://sites.google.com/a/trakia-uni.bg/artte/}

\subsection{2. $\mathrm{Pb}, \mathrm{Zn}, \mathrm{Cu}$ and $\mathrm{Cd}$ content in stems}

The content of heavy metals in the stems of studied cereal crop was considerably lesser than in roots, indicating that their transport via the vascular tissue system was very restricted. According to Wagner [31], the roots of wheat control the amount of cadmium translocated from plant roots to stems and hence, the amount of metal accumulated in leaves. The translocation mechanisms of heavy metals from roots to stems are still unclear for most plants, including wheat.

It was demonstrated that the root-to-shoot translocation of metals occurs primarily via the xylem. It is reported that $\mathrm{Cd}$ could also occur in the xylem through symplastic transport, but the apoplastic pathway is also probable, especially when cadmium contamination levels are high [32]

After the metals' uptake in stems, a part of them could be redistributed again in plants through the phloem as could be presumed from data reported for zinc in wheat [33] and data for cadmium [34].

The highest concentrations in wheat stems were established in plants farmed $100 \mathrm{~m}$ away from the NFMW where $\mathrm{Pb}$ attained up to $0.362 \mathrm{mg} \cdot \mathrm{kg}^{-1}, \mathrm{Zn}-\mathrm{up}$ to $29.426 \mathrm{mg} \cdot \mathrm{kg}^{-1}, \mathrm{Cu}-\mathrm{up}$ to $2.548 \mathrm{mg} \cdot \mathrm{kg}^{-1}$ and $\mathrm{Cd}-$ up to $0.626 \mathrm{mg} \cdot \mathrm{kg}^{-1}$. With shortening of the distance from the NGMW, heavy metal content in wheat stems showed a clear tendency towards reduction. In plants farmed $7000 \mathrm{~m}$ away from the NFMW, Pb decreased up to $0.046 \mathrm{mg} \cdot \mathrm{kg}^{-1}, \mathrm{Zn}-$ up to $11.325 \mathrm{mg} \cdot \mathrm{kg}^{-1}, \mathrm{Cu}-\mathrm{up}$ to $2.625 \mathrm{mg} \cdot \mathrm{kg}^{-1}$ and $\mathrm{Cd}-\mathrm{up}$ to $0.124 \mathrm{mg} \cdot \mathrm{kg}^{-1}$.

\subsection{3. $\mathrm{Pb}, \mathrm{Zn}, \mathrm{Cu}$ and $\mathrm{Cd}$ content in leaves}

The content of heavy metals in wheat leaves was higher than in roots and stems, in agreement with other data reported $[35,36]$. The greater extent of accumulation in the leaves of wheat was probably due both to the uptake of metals from soil through the root system and their translocation through the vascular tissue system, and to particulate matter pollution. The highest concentrations were established in the leaves of wheat farmed $100 \mathrm{~m}$ away from the NFMW with Pb levels up to $92.421 \mathrm{mg}^{\mathrm{kg}}{ }^{-1}$, Zn levels up to $228.329 \mathrm{mg} \cdot \mathrm{kg}^{-1}$, Cu up to $12.957 \mathrm{mg} \cdot \mathrm{kg}^{-1}$ and $\mathrm{Cd}$ up to $10.326 \mathrm{mg} \cdot \mathrm{kg}^{-1}$. Although the heavy metal contents in what leaves was high, there were no symptoms of toxicity. As the distance from the NFMW increased, the leaf metal concentrations tended obviously to decrease - in wheat which was $7000 \mathrm{~m}$ away from the NFMW, Pb decreased up to $1.946 \mathrm{mg} \cdot \mathrm{kg}^{-1}, \mathrm{Zn}-$ up to $0.547 \mathrm{mg} \cdot \mathrm{kg}^{-1}$, $\mathrm{Cu}-$ up to $27.192 \mathrm{mg} \cdot \mathrm{kg}^{-1}$ and $\mathrm{Cd}-$ up to $2.746 \mathrm{mg} \cdot \mathrm{kg}^{-1}$.

\subsection{4. $\mathrm{Pb}, \mathrm{Zn}, \mathrm{Cu}$ and $\mathrm{Cd}$ content in bracts}

The concentrations of studied heavy metals in bracts of the cereal crop was lower than respective levels in leaves, in support to findings of Zupan et al. [37] who also found out lower content of $\mathrm{Cd}, \mathrm{Pb}$ and $\mathrm{Zn}$ in bracts and grain than in leaves.

The accumulation of heavy metals in bracts is airborne and dependent mainly on the type of bracts and the specific heavy metal.

The highest concentrations in bracts were established in wheat located $100 \mathrm{~m}$ away from the Oт NFMW: Pb up to $28.965 \mathrm{mg} \cdot \mathrm{kg}^{-1}$, Zn up to $118.345 \mathrm{mg} \cdot \mathrm{kg}^{-1}$, Cu up to $4.834 \mathrm{mg} \cdot \mathrm{kg}^{-1}$ and $\mathrm{Cd}$ up to $22.717 \mathrm{mg} \cdot \mathrm{kg}^{-1}$. Regardless of the fact that the levels of heavy metals in wheat bracts was high, no toxicity signs were present. With increase of distance from the NFMW heavy metal contents in bracts have markedly declined and in crops $7000 \mathrm{~m}$ away from the NFMW Pb was reduced up to $0.012 \mathrm{mg} \cdot \mathrm{kg}^{-1}, \mathrm{Zn}$ u to $23.574 \mathrm{mg} \cdot \mathrm{kg}^{-1}$, Cu up to $3.574 \mathrm{mg} \cdot \mathrm{kg}^{-1}$ and $\mathrm{Cd}$ up to $0.421 \mathrm{mg} \cdot \mathrm{kg}^{-1}$. 


\subsection{5. $\mathrm{Pb}, \mathrm{Zn}, \mathrm{Cu}$ and $\mathrm{Cd}$ content in grain}

The content of heavy metals in grain was lower than in bracts. The results evidenced that bracts are a sort of obstacle to the pathway of heavy metals to the grain. Heavy metals accumulation in grain occurs probably via the vascular tissue system and depends mainly on the crop species and the specific heavy metal element. As the distance from the NFMW increased, the pollutants' content in the grain of the studied cereal crop was reduced. The highest values were found out in wheat farmed $100 \mathrm{~m}$ away from NFMW, where $\mathrm{Pb}$ attained up to $10.689 \mathrm{mg} \cdot \mathrm{kg}^{-1}, \mathrm{Zn}-$ up to $71.458 \mathrm{mg} \cdot \mathrm{kg}^{-1}, \mathrm{Cu}-$ up to $4.583 \mathrm{mg} \cdot \mathrm{kg}^{-1}$ and $\mathrm{Cd}-$ up to $1.211 \mathrm{mg} \cdot \mathrm{kg}^{-1}$. Heavy metal contents in wheat grain declined markedly as the distance from the NFMW increased: in grain farmed $7000 \mathrm{~m}$ away from the NFMW Pb decreased up to $0.008 \mathrm{mg} \cdot \mathrm{kg}^{-1}, \mathrm{Zn}-$ up to $29.265 \mathrm{mg} \cdot \mathrm{kg}^{-1}, \mathrm{Cu}-\mathrm{up}$ to $3.986 \mathrm{mg} \cdot \mathrm{kg}^{-1}$ and $\mathrm{Cd}-\mathrm{up}$ to 0.021 $\mathrm{mg} \cdot \mathrm{kg}^{-1}$.

According to the results, 100 m away from NFMW wheat grains accumulated $\mathrm{Pb}, \mathrm{Zn}$ and $\mathrm{Cd}$ in amounts higher than the permissible concentrations while in grains $7000 \mathrm{~m}$ away from the NFMW the concentrations were below the MPL.

\subsection{Statistical analysis of results}

The statistical analysis of results was done with SPSS for Windows software.

Correlation analysis between the content of studied elements in the soil and respective concentrations in roots, stems, leaves, bracts and grain was performed.

The results presented in Tables 6, 7 and 8 demonstrated positive correlation $(r>0)$ and a strong linear relationship between variables $(r>0.8)$. The strongest correlation was observed between the total soil content of zinc and its levels in roots, stems, leaves, bracts and grain ( $r$ $=0.998$ ).

Table 9 shows a negative relationship $(r<0)$ between soil $\mathrm{Cu}$ content and its content in leaves. This is the lowest established numerical value of the correlation coefficient $(r=-0.671)$, indicating a moderate strength of the relationship.

\section{CONCLUSIONS}

- The presented results for heavy metals' content in wheat allowing concluding that there was a clear species-specific pattern of accumulation of heavy metals in vegetative and reproductive organs of the cereal crop. With this regard, wheat belongs to the group of moderate accumulators.

- In industrially polluted regions, wheat farming for consumption is unacceptable. This is supported by the fact that grains accumulate $\mathrm{Pb}, \mathrm{Zn}$ and $\mathrm{Cd}$ in amounts exceeding the maximum permissible limits and could pose a risk for human health.

- Also, wheat could be farmed in industrially polluted areas only if intended for seed production or processing - the grain could be used in ethanol production, and straw - for production of cellulose.

\section{REFERENCES}

[1] Kabata Pendias A. \& Mukherjee A. (2007). Trace Elements from Soil to Human. SpringerVerlag, Berlin, 2007.

[2] Alfaro M., Montero A., Ugarte O., do Nascimento C., de Aguiar Accioly A., Biondi C. \& da Silva Y. (2015). Background concentrations and reference values for heavy metals in soils of Cuba. Environ Monit. Assess., Vol. 187, (2015), pp. 4198-4208. 


\section{ARTTIE $Y$}

Ipplied Resseirlohes in Technics, Technologies and Bductation

Journal of the Faculty of Technics and Technologies, Trakia University https://sites.google.com/a/trakia-uni.bg/artte/

[3] Zaprjanova P., Dospatliev L., Angelova V. \& Ivanov K. (2010). Correlation between soil characteristics and lead and cadmium content in the aboveground biomass of Virginia tobacco. Environmental Monitoring and Assessment, Vol. 163, (2010), pp. 253-261.

[4] Akinyele I. \& Shokunbi O. (2015). Comparative analysis of dry ashing and wet digestion methods for the determination of trace and heavy metals in food samples. Food Chemistry, Vol. 173, (2015), pp. 682-684.

[5] Ali Z., Malik R., Shinwari Z. \& Qadir A. (2015). Enrichment, risk assessment, and statistical apportionment of heavy metals in tannery-affected areas. Int. J. Environ. Sci. Technol., Vol. 12, (2015), pp. 537-550.

[6] Alloway B. (1995). Heavy Metals in Soils. Blackie Academic \& Professional, London, 1995.

[7] Chen M., Xu P., Zeng G., Yang Ch., Huang D. \& Zhang J. (2015). Bioremediation of soils contaminated with polycyclic aromatic hydrocarbons, petroleum, pesticides, chlorophenols and heavymetals by composting: Applications, microbes and future research needs. Biotechnology Advances, Vol. 33, (2015), pp. 745-755.

[8] Adriano D.C. (2001). Trace Elements in the Terrestrial Environment. Springer-Verlag, Berlin, 2001.

[9] Dospatliev L., Zaprjanova P., Ivanov K. \& Angelova V. (2014). Correlation between soil characteristics and iron content in aboveground biomass of virginia tobacco. Bulg. J. Agric. Sci., Vol. 20 (6), (2014), pp. 1380-1385.

[10] Delchev G., Dospatliev L., Katrandzhiev N. \& Stoyanova A. (2015). Durum wheat grain yield and quality influenced by some mixtures of foliar fertilizers and combined herbicides. Cr. Acad. Bulg. Sci., Vol. 68 (9), (2015), pp. 1205 - 1212.

[11] Kostial K. (1986). Cadmium. In Trace Elements in Human and Animal Nutrition. 5th ed. Mertz W, Ed. San Diego Academic Press, (1986), pp. 319-345.

[12] Lyubenova M., Dineva S., Georgieva N., Miteva T., Karadjova I. \& Parvanova P. (2012). Ecotoxicological assessment model of cultural plant-soil complex treated with waste water. Biotechnol. \& Biotechnol. Eq., Vol. 26 (2), (2012), pp. 2883-2893.

[13] Page A. \& Bingham F. (1973). Cadmium residues in the environment. Residue Rev., Vol. 48, (1973), pp. 1-44.

[14] Goyer R.A. (1997). Toxic and essential metal interactions. Annu. Rev. Nutr., Vol. 17, (1997), pp. 37-50.

[15] Pile L., Rosada J. \& Siepak J. (1999). The influence of dust emission from the "Glogow" copper foundry on heavy metal concentration in agrocenoses. Polish journal of environmental studies, Vol 8, (1999), pp. 107-110.

[16] Rossada J. \& Nijak K. (1999). Concentration of copper foundry in the years 1996-1998. Progress in plant protection, Vol. 39, (1999), pp. 541-543.

[17] Anonymous. (2002). Bulletin for the Environmental Pollution in Bulgaria. Centre for Ecological Monitoring at Ministry of Environment, Sofia. 2002.

[18] Anonymous. (2003). Bulletin for the Environmental Pollution in Bulgaria. Centre for Ecological Monitoring at Ministry of Environment, Sofia. 2003.

[19] White E.J. \& Turner F. (1970). A Method of Estimating Income of Nutrients in a Catch of Airborne Particles by a Woodland Canopy. Journal of Applied Ecology, Vol. 7 (6), (1970), pp. 441-461.

[20] Tiffin L .O. (1972). Translocation of micronutrients in plants, in: Morvedt, J.J., Giordano, P.M., Lindsay, W. L. Micronutrients in Agriculture, Eds. Soil Science Society of America, Madison, Wisconsin, 1972, pp. 199-229.

[21] Bojinova P., Georgiev B., Krasteva V., Chuldjian H. \& Stanislavova L. (1994). Investigation about the heavy metal pollution in soils and agricultural crops in the region of non-ferrous metal works "D. Blagoev". Soil Sci. Agrochem. Ecol., Vol. 4-6, (1994), pp. 3234.

IRTIIE Vol. 5, No. 2, 2017 ISSN 1314-8788 (print), ISSN 1314-8796 (online), doi: 10.15547/artte.2017.02.008 


\section{ARTTIE $Y$}

Ipplied Resseirlohes in Technics, Technologies and Bductation

Journal of the Faculty of Technics and Technologies, Trakia University https://sites.google.com/a/trakia-uni.bg/artte/

[22] Sengalevitch G. (1999). Problems of heavy metals contamination and using the agricultural lands in the region of KCM - AD - Plovdiv. Prilozenie za ekologia kam bjuletin KCM, Vol. 1, (1999), pp. 10-17.

[23] Zhao Y., Han S., Chen Z., Liu J. \& Hu H. (2014). Comparative Study of Heavy Metals in "Soil-Wheat" Systems Between Sewage-Irrigated Areas and Clean-Water-Irrigated Areas in Suburban Beijing. Journal of Environmental Health, Vol. 77 (6), (2014), pp. 28-35.

[24] Tessier A., Campbell P.G.C. \& Bisson M. (1979). Sequential extraction procedure for the speciation of particulate trace metals. Anal. Chem., Vol. 51, (1979), pp. 844-850.

[25] Ure A.M., Davidson C.M. \& Thomas R.P. (1995). Single and sequential extraction schemes for treemetal speciation in soil and sediments. In Quality Assurance for Environmental Analysis. Quevauviller, P.H., Maier, E.A., and Griepink, B., Eds. Elsevier, Amsterdam, (1995), pp. 505-523.

[26] Chary Sh., Kamala C.T. \& Raj D.S. (2008). Assessing risk of heavy metals from consuming food grown on sewage irrigated soils and food chain transfer. Ecotoxicol. Environ. Saf., Vol. 69 (3), (2008), pp. 513-524.

[27] Sajwan K., Ornes W., Youngblood T. \& Alva A. (1996). Uptake of soil applied cadmium, nickel and selenium by bush beans. Water, air and soil pollution, Vol. 91, (1996), pp. 209217.

[28] Malan H. \& Farrant J. (1998). Effects of the metal pollutants cadmium and nickel in soybean seed development. Seed science research, Vol. 8, (1998), pp. 445-453.

[29] Aranjo do Nascimento C. \& Pereira J. (1997). Uptake and distribution of cadmium and micronutrients by bean cultivars exposed to cadmium levels. Pesquisa agropecuaria brasileira, Vol. 32, (1997), pp. 1303-1308.

[30] Sanchez M., Calzada A. \& Bueno A. (1999). The Cdc6 protein is ubiquitinated in vivo for proteolysis in Saccharomyces cerevisiae. J. Biol. Chem., Vol. 274 (13), (1999), pp. 90929097.

[31] Wagner R.K. (1988). Causal relations between the development of phonological processing abilities and the acquisition of reading skills: A meta-analysis. Men ill-Palmer Quarterly, Vol. 34, (1988), pp. 261-279.

[32] Senden M., Vandermeer A., Verburg T. \& Wolterbeek H. (1995). Citric acid in tomato plant roots and its effect on cadmium uptake and distribution. Plant Soil, Vol. 171, (1995), pp. 333-339.

[33] Herren T. \& Feller U. (1994). Transfer of zinc from xylem to phloem in the peduncle of wheat. Journal of Plant Nutrition, Vol. 17 (9), (1994), pp. 1587-1598.

[34] Cakmak I., Ozkan H., Braun H.-J., Welch R.M. \& Romheld V. (2000). Zinc and iron concentrations in seeds of wild, primitive and modern wheats. Food Nutr. Bull., Vol. 21, (2000), pp. 401-403.

[35] Wagner G.J. \& Yeargan R. (1986). Variation in cadmium accumulation potential and tissue distribution of cadmium in tobacco. Plant Physiol., Vol. 82, (1986), pp. 274-279.

[36] Leifa L., Nobili M., Mondini C. \& Baca Carcia M. (1993). Response of Leguminosae to cadmium ehposure. Journal of plant nutrition, Vol. 10, (1993), pp. 2001- 2012.

[37] Zupan J. \& Zambryski P. (1997). The Agrobacterium DNA transfer complex. Crit. Plant Sci., Vol. 16, (1997), pp. 279-295. 